\title{
Gender and Poetry in Muslim Spain: Mapping the Sexual-Textual Politics of Al-Andalus
}

\author{
O. Ishaq Tijani \\ Department of General Undergraduate Curriculum Requirements \\ University of Dubai, UAE \\ Imed Nsiri \\ Department of Arabic and Translation Studies, \\ American University of Sharjah, UAE
}

\begin{abstract}
This article revisits the role of women in the Andalusian literature and culture of the period between the $8^{\text {th }}$ through the $15^{\text {th }}$ centuries C.E. Drawing on some Western sexual-textual political models of analysis, the article reexamines the literary methods and devices employed by selected Andalusian women poets to demonstrate their intellectual equality with men. Moreover, by providing a sexual-textual political reading of some of the women's poems and/or the anecdotes $(a k h b \bar{a} r)$ about them, the article demonstrates how these women exerted their social and political agency in a male-dominated society. The article seeks to bolster an argument that the frequent mention of the preponderance of women poets - their names and the anecdotes about themsuggests the existence of a female literary sub-culture in al-Andalus that was more vibrant than has been documented in the male-authored classical Arabic texts.
\end{abstract}

Keywords: Muslim Spain, poetry, sexual-textual politics, women and gender

Cite as: Tijani, O. I., \& Nsiri, I. (2017). Gender and Poetry in Muslim Spain: Mapping the Sexual-Textual Politics of Al-Andalus. Arab World English Journal for Translation \& Literary Studies, 1(4). DOI:http://dx.doi.org/10.24093/awejtls/vol1no4.4 